\title{
A NEW INTERPRETATION OF TECHNOLOGICAL PROGRESS
}

V itali Gorokhov, Russian A cademy of Sciences and U niversity of Karlsruhe

\section{WHAT IS THE PHILOSOPHY OF TECHNOLOGY?}

The first question customarily discussed in talking about philosophy of technology is, What is it? What is the philosophy of technology? We can, of course, define it simply as reflection on technology-or, better still, reflection on technological development. Carl M itcham, inThinking through Technology (1994), discusses two kinds of philosophies of technology:

-engineering philosophy of technology (where M itcham cites Kapp, Engelmeyer, and Dessauer, among other technically-trained authors); and

-humanities philosophy of technology (where he includes M umford, Ortega y Gasset, Heidegger, and Ellul).

I think it is better to talk about:

- philosophical reflections of engineers (where I would add Reuleaux and the Technik and Kultur group of the Society of German Engineers), as well as leaders in engineering-based industrial firms (Siemens, Daimler, Benz, Diesel, and $\mathrm{M}$ arconi, among others);

- philosophy of technology as it is typically construed (reflections of Kapp and Dessauer in Germany or Engelmeyer in Russia), where the practitioners may not have been philosophers in the professional sense, though they were clearly philosophers of technology; and

- philosophical criticism of our technological age (where I would add Berdyaev to M itcham's " humanities" list).

We can also talk about philosophy of technology in relation to other subfields in philosophy-philosophy of science, for example, or philosophy of 
economics-or in relation to various approaches to philosophy (methodology, epistemology, axiology-as F erré does in his textbook, Philosophy of Technology, 1988).

No matter the groups into which we divide philosophies of technology, all the authors must face a still more basic question, What istechnology?

\section{WHAT IS TECHNOLOGY?}

A variety of answers to this question have been around since the beginning of the twentiety century. Some have been broad: technology is the same as technique, any goal-oriented activity-but most prominently the activities of technical professionals (M ayer, 1908); or technology is organization (the Polish school of praxiology).

O thers have talked about technology in a narrower sense: as being coeval with being human (Homo faber; see W endt, 1906); or as just one form of human activity, especially the conscious organization of materials for cultural purposes; or technology is only industrial technology.

With respect to the concept of "technology," I think the principal assigned meanings have been three:

(a) Technology (as techniques) is the aggregate of all the artifacts humans have ever used, from primitive tools to the most complex large-scale technological system.

(b) Technology is the aggregate of all technical activities: invention and discovery; research and development, including basic design; final design and actual implementation, including the organizing of manufacturing facilities; and the steps in successful technological invention: thoughtful designing or planning; embodiment in models and actual implementation; and marketing to society at large.

(c) Technology is the aggregate of all technical knowledge, from the most specialized techniques and practices to large-scale theoretical scientifictechnological systems involving engineering knowledge and know-how. 
In my opinion, all these definitions or meanings-which are appropriately spoken of as "thinking about technology"-miss the most important aspect of all. That is what really ought to be meant by $M$ itcham's phrase, "thinking through technology" - namely, the philosophizing actually done by practitioners of technology. It is not always recognized as such by them, but it is the internal selfreflections of the technical community. A nd I think the most fundamental task of philosophers of technology ought to be to elucidate this often invisibleinner philosophy of technologists themselves-including its impact on the history of our culture right down to the present.

\section{TECHNOLOGICAL SELF-REFLECTION IN THE HISTORY OF CULTURE}

Technical activity, which has characterized humankind since its earliest days, turned into engineering in the modern sense when engineers aligned themselves with science in regularly applying scientific knowledge to technical practice. Or, somewhat later, when engineers adopted a scientific view of the world, acquired professional status, and initiated the course of modern engineering education.

Since the Renaissance, modern culture has been oriented toward the future-toward creation by design, invention, and technical progress. Earlier cultures might best be called "canonical," based on time-honored traditions. So inventors in the modern sense could not have been part of these cultures-though there certainly were inventions, and even a sort of design function latent in earlier canons that eventuated in modern design culture. And I would say it was this hidden design aspect that actually constituted the philosophy, in the sense of selfreflection, of the technologies of these earlier cultures.

So we can describe various (often hidden) self-reflective philosophies within technical communities in the history of culture.

(a) The earliest philosophies within the earliest technologies were part of traditional canonical cultures:

- Techniques were accompanied by the "knowledge" embedded in mythology-where we might talk about myths as embryonic project designs. 
Practitioners either used natural tools for adaptation to the natural environment (as emphasized in Schilling's P hilosophie der Technik, 1961) in an organic style of technology; or else they began the conscious introduction of newly-devised tools, as instruments for creating a new environment ("second nature").

-Two principal ways of reflection appeared in these early cultures: one insisted on maintaining the existing natural and social order by way of specific practices (e.g., in ancient China as discussed by N eedham) or ways of preserving harmony between society and nature (e. g., in India); the other involved aggression against or attacking nature or the natural environment in the name of human society (M umford's "myth of the machine," including the organized social activities of "megamachines").

-Techniques existed without science and science without technology.

-In antiquity, handcrafts yielded objects of art; though philosophical/scientific knowledge might be involved, there was no orientation toward experimental sciences in the modern sense, nor were there science-based production methods. Sometimes, mechanical inventions were devised to illustrate science, to show the power of scientific demonstrations, or to amaze the public. But these had no impact on handcrafts.

-A naximander's mechanical models of the universe and A rchimedes' technological gadgets were pre-technological (though it is not impossible to speak of A rchimedes as an engineer before the fact).

-Finally, medieval technological progress was constrained by a rule that "master" work could be no worse and no better than the standard. The craftsman was hidebound, working exactly as his forefathers had, with no more than their experience as his guides. Fearful of competition, craft guilds opposed innovations and inventions, viewing them as repugnant or as encroaching on their privileges. The guilds even banned inventions, along with the products based on them, as well as advertising for them, especially if they promised goods for prices lower than those set by the guilds. Inventors were even persecuted. One example is a declaration of the municipal council of Cologne in 1412: "L et it be known that a W alter Kesenger came to us with a proposal to build a wheel for spinning silk threads. A fter deliberation and discussion with their friends, the council has 
found that many people in our city who spin silk for a living would be ruined. It has therefore been declared that no spinning wheel shall be built and installed, now or at any time hereafter."

(b) The beginnings of a design culture appeared in the Renaissance or the "New Age":

-Petrus Peregrinus of $M$ aricourt (see hisE pistola de magnete) and Roger Bacon, with his engineering fantasies, had already, in the M iddle A ges, taken a step toward a design culture. Roger Bacon wrote about grinding lenses, building an instrument in which, "A child might look like a giant, or a man like a mountain." $M$ any of his writings were already engineering fantasies, no longer mythological fantasies, since they were based on a recognition of the practical, creative power of knowledge in opposition to mythical thought.

- Technology and engineering as a new profession-joining craftsman, scientist, and engineer-came to be a possibility in the Renaissance. That was when it began to be common for an inventor to claim rights-as opposed to the practice, in the Middle A ges, according to which an innovator would ascribe his creation, novel treatise, or invention to some authority, divine or human. Polidore V ergil, in De inventoribus rerum (1499), complained that it was impossible to name the individuals responsible for almost any ancient invention. They remained anonymous on principle. Just the opposite in the Renaissance, when individuals took credit for rediscovering things already known in ancient times. The newly-designated engineer claimed that, like the Divine Creator, he was creating new realities. At the outset, he would claim to be imitating the Creator, but gradually he came to think of himself as creating a world, a "second nature."

-Technology was now joined to experimental science and experimental techniques; craft techniques were combined with scientific technology-as in the work of Galileo, William Gilbert, and Christian Huygens. Galileo was responsible for more than the beginnings of experimentation; he also showed how scientific knowledge can be manipulated for technical purposes. In his "new science," Galileo was as willing as a modern engineer to manipulate nature: "If the terrestrial globe were pierced through its center..." He paved the way for the engineer's way of thinking and theorizing, but also for his practices. For 
example, he clearly paved the way for his younger contemporary, Huygens, who imitated Galileo in applying a geometric model to physical processes to account for the periodicity of pendulums-from which he generated the diagram for a technical design. In this, he went beyond Galileo and came up with a new design for a device-the pendulum clock.

- O ne other development deserves mention here, the first hints of technocracy or expertocracy in the work of Francis Bacon, with his ideas about nature as an instrumental laboratory. This was, of course, just a hint, when compared with the modern era.

(c) The transformation of modern engineering practice and scientific technology into a true "design culture" (see Gorokhov, Engineering: Art and Science, 1990):

-This transition came in stages: (i) engineering before the emergence of the engineering sciences (more technicians than engineers); (ii) technology as applied science and the beginnings of engineering sciences (engineering practice takes on a definite structure); and (iii) the organization of modern engineering practice, including interdisciplinary research and systems engineering.

-Within modern technology, there are different kinds of self-reflective "philosophies," including:

i) a systems philosophy of project management, making explicit use of the methodology of systems engineering (designing here or there leading to design everywhere-the "principle" of a design culture);

ii) social technology or organizational design-the design of societies, from the local to the global-where there is a need to be aware of the limits of a design culture, to avoid social engineering because a society cannot be totally artificial; the most that is possible is societies that combine the artificial with the natural;

iii) information technology, including the use of A rtificial Intelligence 
to produce new sorts of designs (e.g., using "expert systems"); this approach emphasizes the theoretical dimension of technology-design and research become interchangeable, as there is an erosion of boundaries between the two;

iv) biotechnology, where there is a special need for a new sort of engineering ethics to emphasize the limits of technological development imposed by the biological nature of human beings; and

v) environmental technology, with its demand for sustainable develop ment,

\section{for} setting limits

on

technol

ogical

develop

ment by

emphasi

zing the

place of

humank

ind

within

the biosphe

re.

\section{REPRISE: BACK TO THE QUESTION: WHAT IS THE PHILOSOPHY OF TECHNOLOGY?}

The things that philosophy of technology should study include: the technological phenomenon as a whole; the place of technology within the development of society as a whole (and not just the development of technology in isolation); and the historical dimension, both retrospective and prospective. 
To define the object of the study of philosophy of technology appropriately, it is necessary to distinguish technological knowledge from technological activity, and, further, to recognize a "technological consciousness."

The product of technological activity is artifacts-both technical equipment and techniques.

The product of technological knowledge is technological activity. That is to say, technological knowledge is a prescription for technological activity-and thus, ultimately, for technological artifacts.

The product of technological consciousness or technological understanding is an explanation of the role of technology, of technological activity and technological knowledge, within the history of modern culture.

In other words, the object of investigation in the philosophy of technology is primarily to focus on the technical or engineering sciences: technical (including engineering) products, activities, and knowledge as cultural phenomenon; and the development of technological consciousness, especially the self-understanding-by engineers and other technical personnel-of engineering practice and technical knowledge.

In short, the principal purpose in doing philosophy of technology is to study the relationship between human beings and the world as manifested in a technological view of the world.

\section{PHILOSOPHY OF TECHNOLOGY, PHILOSOPHY OF SCIENCE, PHILOSOPHY OF ECONOMICS, AND PHILOSOPHY OF THE ENVIRONMENT}

To conclude, if we think of technology as creating a new environment (a "second nature" ), then there have been three phases in the development of modern technology: linking technology to science, linking it to economics, and linking it to the environment. The "new" philosophy of technology must go beyond the study of scientific-technological development alone to include a philosophy of the environment-indeed, to include a philosophy of sustainable development. 
Philosophy of technology, in the future, can become an integral part of technology itself. But to do so, it cannot stand outside, as mere methodological reflection; it must become an organic part of technology proper. Today, we can no longer simply apply scientific knowledge to produce new technologies. (That was the old "scientization" of technology.) Today and in the future, we must transform engineering and technological education by focusing onsystems and reflection. 